Laporan Kasus

\title{
Neglected-Noncompliant Type 1 Diabetes Mellitus with Complications
}

\author{
Afdal, Eka Agustia Rini
}

\begin{abstract}
Abstrak
Diabetes mellitus (DM) tipe 1 merupakan kelainan sistemik akibat terjadinya gangguan metabolisme glukosa yang ditandai oleh hiperglikemia kronis. Keadaan ini disebabkan oleh proses autoimun yang merusak sel $\beta$ pankreas sehingga produksi insulin berkurang bahkan terhenti, penderitanya akan memerlukan asupan insulin eksogen. Penyakit ini menimbulkan komplikasi kronik sehingga memerlukan manajemen pengobatan yang berkelanjutan dan edukasi pada pasien serta keluarganya. Penyakit yang tidak terkontrol akan menimbulkan berbagai komplikasi metabolisme, gangguan makrovaskular dan mikrovaskular yang menyebabkan penurunan kualitas dan harapan hidup penderita.
\end{abstract}

Kata Kunci : Diabetes melitus tipe 1, makrovaskular, mikrovaskular

\begin{abstract}
Diabetes mellitus (DM) type 1 is a result of the systemic disorder of glucose metabolism disorder characterized by chronic hyperglycemia. This situation is caused by the autoimmune processes that destroy pancreatic $\beta$ cells resulting in the production of insulin is reduced even halted, the sufferer will require exogenous insulin intake. This raises the complications of chronic disease that requires ongoing medication management and education for patients and their families. Uncontrolled disease will cause various metabolic complications, macrovascular and microvascular disorders that cause loss of quality and life expectancy of the patient.
\end{abstract}

Keywords: Type 1 diabetes mellitus, macrovascular, microvascular

Affiliasi penulis : Bagian IImu Kesehatan Anak Fakultas Kedokteran Universitas Andalas/RS Dr. M. Djamil Padang

Korespondensi : Afdal, Bagian IImu Kesehatan Anak Fakultas Kedokteran Universitas Andalas/RS Dr. M. Djamil Padang, afdaldr@yahoo.com

\section{Introduction}

Type 1 diabetes mellitus (DM) is a progressive disease with risk factors for both macrovascular and microvascular complication. Uncontrolled diabetes mellitus results in complex metabolic and structural alterations, leading to abnormal carbohydrate, lipid, and protein metabolism, as well as long-term complications involving vascular tissue, kidney, and nerve. The long-term effects of DM include progressive development of specific long-term complication of retinopathy with potential blindness, nephropathy that may lead to end-stage renal failure, and/or neuropathy with the risk of foot ulcers, amputation, and feature of autonomic dysfunction. The complications of peripheral vascular and cerebrovascular disease lead to significant disability and in many cases premature mortality, and the disease imposes significant human and financial cost on the patients and the communities. ${ }^{1}$

Prevention of long-term microvascular and macrovascular complications of diabetes must begin during the pediatric age range because there is no "grace" period. Complications appear very early in the course of diabetes, perhaps at the onset of disease, and the earliest stages often can be seen within 2 to 5 years after diagnosis. Because the long-term complications are affected by diabetes duration and glycemic control, appropriate diabetes management aimed at reducing glycemic burden is critical for all affected children and youth. The diabetes control and complication trial (DCCT) showed that intensive diabetes management was associated with the following percent risk reductions primary retinopathy (76\%), progression of retinopathy $(54 \%)$, development of proliferative or severe nonproliferative retinopathy $(47 \%)$, microalbuminuria $(39 \%)$, Frank albuminuria $(54 \%)$, clinical neuropathy $(60 \%){ }^{2}$

In caring for children with diabetes, professionals need to understand the importance of involving adult in child's diabetes management. Young children including school-aged children are unable to provide their own diabetes care and middle school and high school students should not be expected to independently provide all of their own diabetes management care. Thus, the education about how to care for a child and adolescent with diabetes must be provided to the entire family unit, emphasizing age and developmentally appropriate self care and integrating this into the child's diabetes management. ${ }^{3}$

Educational interventions have beneficial effects on diabetes management outcomes. Education is a continuous process and should be provided to the child or adolescent and their family at diagnosis and repeated as required at follow up. Diabetes education is more than a transfer of knowledge and should aim to result in the appropriate behavior changes needed for achieving and maintaining diabetes control. ${ }^{4}$

The Purpose of this case to reminds us that the poor compliance of type $1 \mathrm{DM}$ patient results in an increased incident of its complication.

\section{Case Report}

A 11 years 10 months old girl, AS, has been consigned from dr Ahcmad Mochtar hospital Bukittinggi with diabetic ketoacidosis. Patient was admitted to pediatric ward dr. M. Djamil hospital from 
April $17^{\text {th }}$ to May $5^{\text {th }} 2009$ with Chief complain Decreased of consciousness since 7 hours before admission. Patient had been known got diabetes mellitus since 3 year ago, treated by pediatrician in Bukittinggi, control twice a month and got regular insulin $8 \mathrm{IU}$ twice daily. Patient drink frequently since 3 year ago, frequency \pm 12 glasses/day, 1-2 glasses/time and patient easy to tired. Body weigh looked decreased rapidly since 1 month ago, the highest body weight was $33 \mathrm{~kg}$. Right ear was Itch since 1 day ago, patient crowbar it, than the ear out a clear secret, not smell. And 10 hours ago the right ear got bleeding, no history of trauma. Fever since 7 hours before admission, high and continue. Decreased of consciousness since 7 hours before admission. No seizure and vomits. No visual disturbance, no numbness, pain, paraesthesia. Patient eaten three times a day (rice 1 glass at breakfast, 1.5 glass at lunch and 1 glass at diner, egg or meat, fish and vegetable), between meal, patient got snack and fruit. Patient admission of $8 \mathrm{IU}$ regular insulin 15 minutes before breakfast and dinner. Frequency of urinate increased 7-10 times/day, quantity a half glass each time, normal color. Patient had been brought up to Achmad Mochtar hospital before, and had random blood glucose $479 \mathrm{mg} / \mathrm{dl}$, keton bodies $(++)$, then consigned to dr. M. Djamil hospital with normal salin infusion, used up $400 \mathrm{cc}$.

Patient had been experienced decreased of consciousness three times before. First, 3 years ago, hospitalized in Achmad Mochtar hospital for 3 days and discharged with 5 IU regular insulin twice daily. Second, 6 months later, hospitazed for 1 week and discharge with $8 \mathrm{IU}$ regular insulin. And the third, 3 months later, hospitalized for 3 days and discharge with $8 \mathrm{IU}$ regular insulin. The patient was forced discharge to each admission. The pediatrician had been explained to her family that patient should refer to M. Djamil hospital to get better diabetes management since there was a pediatric endocrinologist at M. Djamil hospital, but the family refused. Patient was in low social economic status and medical treatment was public charge by jamkesmas. Her mother was 45 year old, (body height $151 \mathrm{~cm}$ ), "PGA" graduated, house wife. Her father was 42 year old (body height 160), senior high school graduated, work as farmer with income \pm Rp 30.000 /day. Patient and her family live in Tilatang Kamang-Agam Regency.

General appearance was severely ill, unconscious (GCS $3=E 1 M 1 V 1$ ). Blood pressure $90 / 50 \mathrm{mmHg}$, pulse rate $124 \mathrm{x} /$ minute respiratory rate $36 \mathrm{x} /$ minute (deeply), and body temperature $39{ }^{\circ} \mathrm{C}$. Body weight was $25 \mathrm{~kg}$ (<P 3 CDC growth chart 2000), body height was $136 \mathrm{~cm}$ (P 3 CDC growth chart 2000, height age 9.5 year, target height $149 \mathrm{~cm}<P 3 \mathrm{CDC}$ growth chard 2000, genetic height potential $140.5 \mathrm{~cm}$ $-157.5 \mathrm{~cm}$ ). Weight for age $62 \%$, height for age $91 \%$, weight for height $79 \%$. Nutritional status was undernourished. No sign of cyanosis, anemic, icteric or oedema. No deformity at head and head circumference was $52 \mathrm{~cm}$ (normal, Nellhaus curve). Skin was warm with less subcutan fat and no crazy pavement dermatosis. There was no enlargement of lymph node. Hair looked quite blonde, difficult to take out. Eyes looked sunken, conjunctiva was not anemic, sclera was not icteric, pupil was isocor, circumfence 3 $\mathrm{mm}$, direct and indirect light reflexes were normal. There was nasal flare. There was edema on meatus acusticus externus of right ear, seroushemoragic discharge, pressure pain and stretched pain tragus and antitragus difficult to evaluate. Throat was in normal limit. Mucosa of mouth and lips were dry, no oral trush, no caries on teeth. JVP $5-2 \mathrm{cmH}_{2} \mathrm{O}$ and no rigidity of neck.

The chest was symmetrical, retraction on epigastrium and intercostals. Heart sound was normal with no murmur, Breath sound vesicular, no rales and whezing. Abdomen was soft, non tender, liver and spleen were not palpable, less skin elasticity and bowel sound was normal. There was general white spot on vulva, edge was eritema, pubertal state A1M1P1. Extremities was warm, refilling capillary was good, no cyanosis. Physiologic reflexes were normal and there were not pathology reflexes and no signs of meningeal signs.

Hemoglobin $14.5 \mathrm{~g} \%$, WBC $30.400 / \mathrm{mm}^{3}$, DC 0/1/11/69/13/6. Random blood sugar $581 \mathrm{mg} / \mathrm{dl}$. urine reduction $(++)$, keton bodies $(++)$, protein $(-)$, bilirubin (-) Urobilin (+), leucocyte (-). Fecal examination were normal. Blood gas analysis: $\mathrm{pH} 6.8$; PCO2 $10 \mathrm{mmHg}$; PO2 $158 \mathrm{mmHg}$; $\mathrm{HCO} 3$ and BE were unmeasureable, saturation $95 \%$. Sodium $141 \mathrm{mEq} / \mathrm{L}$ (true value was $150 \mathrm{mEq} / \mathrm{L}$ ) Corrected sodium concentration can be calculated as: sodium $+[2 \times$ (glucose -5.5$)] / 5.5$ (all values in $\mathrm{mmol} / \mathrm{L} ; 1 \mathrm{mmol}$ glucose $=18 \mathrm{mg} / \mathrm{dl})$. The calculation can be simplified to $2 \mathrm{mEq} / \mathrm{L}$ of sodium to be added for every $5.5 \mathrm{mmol} / \mathrm{L}$ of glucose above 5.5 $\mathrm{mmol} / \mathrm{L}$. Kalium $4.6 \mathrm{mEq} / \mathrm{L}$.

Diagnsis was diabetic ketoacidosis ec type 1 DM, otitis external, vulvovaginalis candidiacies, undernourish

Patient was managed by regular insulin (RI) $0.1 \mathrm{IU} / \mathrm{kg} /$ hour (50 IU of $\mathrm{RI}$ in $500 \mathrm{cc} \mathrm{NaCl} 0.9 \%$ [25 $\mathrm{cc} /$ hours $=24 \mathrm{drip} /$ minute/micro]), Mannitol 20\% 0.25 $\mathrm{mg} / \mathrm{kg}$ (30 cc) in 30 minutes, cefotaxim $2 \times 1 \mathrm{gram} \mathrm{IV}$, paracetamol $250 \mathrm{mg}$ supposituria, vulva hygiene and clotrimazole cream. Acidosis was corrected by sodium bicarbonate $50 \mathrm{mEq}$ (half of measured dosage $[0.3 \mathrm{x}$ $(15-\mathrm{HCO} 3) \times \mathrm{BW}])$.

12 hours after admission patient was consciousness, fever still continue, no seizure, and no vomit. Moderately ill, GCS 15 (E4M6V5). BP 100/70 $\mathrm{mmHg}$, pulse rate $100 \mathrm{x} /$ minute, respiratory rate 28 $\mathrm{x} /$ minute. temperature $38,1{ }^{\circ} \mathrm{C}$. Others physical examination still same. Blood gas and electrolyte report: $\mathrm{pH}$ 7.32; PCO2 $16 \mathrm{mmHg}$; PO2 $90 \mathrm{mmHg}$; HCO3 $8.2 \mathrm{mmHg}$; BE -15,4; saturation $90 \%$, sodium $144 \mathrm{mEq} / \mathrm{L}$, kalium 3,0 mEq/L.

Random blood sugar $369 \mathrm{mg} / \mathrm{dl}, 455 \mathrm{mg} / \mathrm{dl}$, $261 \mathrm{mg} / \mathrm{dl}, 182 \mathrm{mg} / \mathrm{dl}, 241 \mathrm{mg} / \mathrm{dl}$ consecutively.

Because blood glucose was $<250 \mathrm{mg} / \mathrm{dl}$, we decided to exchange $\mathrm{NaCl} 0.9 \%$ infusion to $2 \mathrm{~A}$ (glucose 10\%) 16 drip/minute/macro. RI drip decreased to 20 drips/minute/micro.

The otolaringologist found otitis externa and gave ofloxacin eardrop 5 drops twice a day and advice to continue antibiotic. The dermatologist did not find vaginal candidacies, she found shallow ulcer and white-wetly squamous in vulva and was diagnosed as banal ulcer, given fucidic acid cream as therapy. The ophthalmologist found no papil edema and there were dot bloody and hard exudates in both of retina and conclusion as moderate non proliferative diabetic retinopathy (NPDR), no specific treatment was given.

Second day, blood glucose was stable with value between $110-150 \mathrm{mg} / \mathrm{dl}$ and keton bodies was negative, we decided to stop RI drip and substitute to 
subcutan insulin with $2 / 3$ of total doses had been given (24 hours) $=2 / 3 \times 60 \mathrm{IU}=45 \mathrm{IU}(8 \mathrm{UI} \mathrm{RI}$ and $12 \mathrm{UI}$ intermediate insulin before breakfast, $9 \mathrm{UI}$ RI before lunch and $8 \mathrm{UI} \mathrm{RI}$ and $8 \mathrm{UI}$ intermediate insulin before dinner). We give oral intake $1900 \mathrm{kkal}$ (recommended to RDA). At the first meal time RI drip still continue until 60 minute after meal and then to be stoped.

We consult about the diet to dietitian and involving mother. The patient got $1900 \mathrm{kkal}$, there were breakfast $20 \%(400 \mathrm{kkal})$ at 06.00 , Lunch $30 \%$ (500 kkal) at 12.00 , dinner $20 \%$ (400 kkal) at 18.00 and snack $10 \%$ (200 kkal) at 09.00, 15.00 and 21.00. Blood glucose was checked 7 times daily, 30 minute before and 2 hour after meal time and at mid night. To sure the patient got accurate diet, controlling did by dietitian, family, nurse and doctor. We gave education to patient and parent, explained about type $1 \mathrm{DM}$, how it important to control blood glucose to prevent complication and the rule of insulin (types, doses, how to inject, location of injection, storage).

Patient condition was better day by day. Blood glucose were still not stabile with range 85 $154 \mathrm{mg} / \mathrm{dl}$ before breakfast, 100 - $202 \mathrm{mg} / \mathrm{dl}$ after breakfast, $84-171 \mathrm{mg} / \mathrm{dl}$ before lunch, $66-221 \mathrm{mg} / \mathrm{dl}$ after lunch, $67-256 \mathrm{mg} / \mathrm{dl}$ before dinner, $57-311$ $\mathrm{mg} / \mathrm{dl}$ after dinner and $65-141 \mathrm{mg} / \mathrm{dl}$ at mid night. So we adjust dose of insulin based on basal bolus system. At the $10^{\text {th }}$ day, before breakfast insulin doses was $8 \mathrm{IU} \mathrm{RI}$ and $13 \mathrm{IU}$ intermediate insulin, before lunch was $6 \mathrm{IU} \mathrm{RI}$, before dinner was $4 \mathrm{IU} \mathrm{RI}$ and $5 \mathrm{IU}$ intermediate insulin $(1.3 \mathrm{lU} / \mathrm{kg})$. Education to patient and family continues every day about type $1 \mathrm{DM}$, used of insulin, basic diet advice, blood glucose monitoring, normal blood glucose level and glucose target, acute and chronic complications, exercise, and management during illness.

Mother could take and inject insulin by herself under a doctor's order especially in adjusted insulin doses, parent still had mistaken amount of insulin to be given based on daily blood glucose with basal bolus regiment. Blood glucose and doses of insulin were fill in a log book. Patient and family learn modification of diet from dietitian (kind and amount of food). HbA1c and C-peptide could not be done cause of no cost. Vital sign and other physical examination were normal. Blood glucose level relatively stable, the most value ranged between $100-190 \mathrm{mg} / \mathrm{dl}$, doses of insulin were $9 \mathrm{IU} \mathrm{RI}$ and $15 \mathrm{IU}$ intermediate insulin for breakfast, $6 \mathrm{IU} \mathrm{RI}$ before lunch, $4 \mathrm{IU} \mathrm{RI}$ and $5 \mathrm{IU}$ intermediate insulin before dinner, totally $1.4 \mathrm{lU} / \mathrm{kg}$.

At $18^{\text {th }}$ day, patient want to discharge but since we doubt about the compliance of patient and her family that they still couldn't adjusted the dosage of insulin by themselves, we did not permitted them. Even though, the family forces to discharge with much reason. Condition of the patient was good. There were no any complaints. BW $30 \mathrm{~kg}$ (P 3-10 CDC 2000), blood glucose quite stable (100-180 mg/dl). She was given $1900 \mathrm{kkal}$ and diet guideline from dietitian. Patient had a portable blood glucose meter and could use it. We give advice to the patient and family especially mother to take diet suitable with the guideline, check blood glucose every day and record in a log book, inject insulin before breakfast, lunch and dinner. Patient and family were reminded about the signs and symptoms of hypo and hyperglycemia, and if she was suspected in hypo or hyperglycemia or the patient had problems (such as she gets sick, doesn't want to eat, etc), they can contact a doctor and control every month.

The first control was 3 month after discharge. Patient was accompanied by mother. There was sometimes the symptom of diabetes (polypagi, polyuria and polydipsia), no visual disturbance, no numbness, pain, paraesthesia. The insulin sometimes was not injected especially in the afternoon since the patient was being at school. The insulin dosage was not followed the instruction given before. Doses of insulin were $15 \mathrm{IU} \mathrm{RI}$ and $5 \mathrm{IU}$ intermediate insulin for breakfast, $5 \mathrm{IU} \mathrm{RI}$ before lunch, $7 \mathrm{IU} \mathrm{RI}$ and $4 \mathrm{IU}$ intermediate insulin before dinner, totally $1.2 \mathrm{IU} / \mathrm{kg}$. Blood glucose was not routinely checked, only being examined once a day at most, with the range of 61 $170 \mathrm{mg} / \mathrm{dl}$. Blood pressure was $110 / 60 \mathrm{mmHg}$, body weight was $30 \mathrm{~kg}(\mathrm{P}<3 \mathrm{CDC} 2000)$, body height was $137 \mathrm{~cm}(P<3$ CDC 2000). There was no skin infection and lipoatropy or lipohypertrophy. Pubertal state was A1M1P1. Physiological reflexes were normal. Patient and parent was given reeducation especially about complications, advised patient to measure blood glucose more frequently and contact us to adjust doses of insulin

The second control was 2 months later. Patient accompanied by mother. Patient never contacts us, and if we contact her and family, they report that she was in a good condition. There was sometimes the symptom of diabetes (polypagi, polyuria and polydipsia), no visual disturbance, no numbness, pain, paraesthesia. The insulin was still not routinely administered, especially at noon. The insulin dosages were not followed instruction. Doses of insulin were $6 \mathrm{IU} \mathrm{RI}$ and $5 \mathrm{IU}$ intermediate insulin for breakfast, $5 \mathrm{IU} \mathrm{RI}$ before lunch, $8 \mathrm{IU} \mathrm{RI}$ and $6 \mathrm{IU}$ intermediate insulin before dinner, totally $1 \mathrm{lU} / \mathrm{kg}$. Blood glucose was not routinely checked, only being examined once a day at most, with the range of 81 $130 \mathrm{mg} / \mathrm{dl}$. Blood pressure was $110 / 70 \mathrm{mmHg}$, body weight was $30 \mathrm{~kg}(\mathrm{P}<3 \mathrm{CDC} 2000)$, body height was $137 \mathrm{~cm}(\mathrm{P}<3 \mathrm{CDC} 2000)$. There was no skin infection and lipoatropy or lipohypertrophy. Pubertal state was A1M1P1. Physiological reflexes were normal.

Eight months after discharge, there was sometime symptom of diabetes (polypagi, polyuria and polydipsia), no visual disturbance, no numbness, pain and paraesthesia. The insulin was still not routinely administered and dosages were still not followed instruction. Doses of insulin were $10 \mathrm{IU} \mathrm{RI}$ and $4 \mathrm{IU}$ intermediate insulin for breakfast, 4 IU RI before lunch, $9 \mathrm{IU} \mathrm{RI}$ and $6 \mathrm{IU}$ intermediate insulin before dinner, totally $1.1 \mathrm{lU} / \mathrm{kg}$. Blood pressure was $110 / 70 \mathrm{mmHg}$, body weight was $33 \mathrm{~kg}(P<3$ CDC 2000), body height was $139 \mathrm{~cm}(P<3 \mathrm{CDC} 2000)$. There was no skin infection and lipoatropy or lipohypertrophy. Pubertal state was $\mathrm{A} 1 \mathrm{M} 1 \mathrm{P} 1$. Physiological reflexes were normal. Urinalysis were reduction $(-)$, protein $(-)$. The patient had a poor compliance in management of her disease. By that, we measure $\mathrm{HbA1c}$, lipid profile and screening for complication, such as nephropathy and reevaluation of eye for retinopathy by the fund of donation.

The measure of $\mathrm{HbA1c}$ was $16.9 \%$ (poor glycaemic control), for lipid: total cholesterol was 250 $\mathrm{mg} / \mathrm{dl} \quad(<200 \mathrm{mg} / \mathrm{dl})$, triglyceride $226 \mathrm{mg} / \mathrm{dl} \quad(<150$ $\mathrm{mg} / \mathrm{dl})$, LDL cholesterol $182 \mathrm{mg} / \mathrm{dl}(<100 \mathrm{mg} / \mathrm{dl})$, HDL cholesterol $48 \mathrm{mg} / \mathrm{dl}$ ( $\geq 40 \mathrm{mg} / \mathrm{dl}$ ). Screening for nephropathy, qualitative microalbuminuria was positive (negative). For future examination of kidney function 
we measure ureum and creatinin with result $25 \mathrm{mg} / \mathrm{d}$ and $0,3 \mathrm{mg} / \mathrm{dl}$ for ureum and creatinin respectively. Reevaluation of eye were visus $5 / 10$ and $5 / 7$ for right and left eye, clear lens of both eye, edema of right macula and decrease fovea reflex with conclusion moderate non proliferative diabetic retinopathy ocular dextra and suggest to monitor 1 month later.

Patient was managed by Captopril $0.1 \mathrm{mg} / \mathrm{kg}$ every 8 hours, low saturated fat intake $(<10 \%$ of energy intake), regular exercise and reeducation and give explanation that complications was found in patient and if she was still in poor compliance, she will be in a great problem in several years later, such as having renal failure and blindness, Suggested other family member with better knowledge involved in management.

\section{Discussion}

Type $1 \mathrm{DM}$ is an autoimmune disease in which the immune system destroys the insulinproducing beta cells of the pancreas that regulate blood glucose. Type $1 \mathrm{DM}$ has an acute onset, with children and adolescents usually able to pinpoint when symptoms began. Onset can occur at any age, but it most often occurs in children and young adults. Since the pancreas can no longer produce insulin, people with type 1 diabetes require daily injections of insulin for life. ${ }^{5,6}$

Every child and adolescent with type 1 diabetes, including those from rural and remote areas, should have access to optimal medical management. Health care professionals who look after children must make advocacy for the child one of their key responsibilities. Children and adolescents should have access to care by a multidisciplinary team trained in childhood and adolescent diabetes. It should be recognized that the members of the management team include the patient with diabetes and his/her family. In rural and geographically remote areas, children with diabetes may be successfully cared for by a local paediatrician/physician with training and experience in pediatric diabetes access to resources, support and advice from a tertiary centre diabetes team. In case of ketoacidosis, a specialist/consultant pediatrician with training and expertise in the management of diabetic ketoacidosis should direct management. ${ }^{4}$ This patient had been labeled as a neglected and noncompliant patient since she and her family always asked for discharge to every admission. In Bukittinggi patient did not get adequate education and treatment. At first admission, she only hospitalized for 3 days so they did not get diabetes education completely, and it was approved by her hospitalization with DKA. In every admission to Achmad Mochtar hospital, she was advised to refer to M. Djamil hospital to get better diabetes management, but she and her family refused that

The most common precipitating factors in the development of diabetic ketoacidosis include infection, often as a result of inadequate insulin therapy during intercurrent illness and insulin omission. ${ }^{4,7}$ The last admission in M. Djamil hospital with DKA precipitating by ear infection and banal ulcer in vulva. The risk factors for DKA were poor metabolic control and previous episodes of DKA. Poor metabolic control for this patient were showed by the present of polyuria and polydipsia, weight loss or failure to gain weight with growth, poor growth, signs of diabetes complications, elevated $\mathrm{HbA} 1 \mathrm{c}$ and elevated blood lipids.

Suboptimal medical management leads to poor diabetes control which may impair growth, delay puberty and lead to irreversible long-term diabetic microvascular and macrovascular complications. Quality of life and life expectancy may be significantly reduced under these circumstances. ${ }^{4,7}$ The growth of this patient was impaired, after 8 months of treatments, based on CDC 2000 growth chart body height was decrease from P3 to $<$ P3. Eventhought her body height was still in the range of height potential genetic and bone age was average girl, it was suggested that poor control of diabetic was contributed to her growth impairment.

Patient was admitted in M. Djamil Hospital after 3 years diagnosis of DM. Along after diagnosis, there were no screenings to long term complications. The microvascular complications were found at the first time in M. Djamil hospital. The ophthalmologist found sign of retinopathy diabetes in this patient. Renal complication (nephropathy diabetic) could not be performed earlier because of financial problem. It was done several months later. There were no sign of neuropathy in this patient.

In the initial stages of retinopathy, patients are generally asymptomatic, however in the more advanced stages of the disease, patients may experience symptoms, including blurred vision, distortion, or visual acuity loss. This patient did not complain about visual disturbance, however from eye examination the visus was impaired, and in retina there were macula edema and decreased fovea reflex of the right eye. Stage of retinopathy is moderate NPDR. Macular edema is the most common cause of vision loss in patients with NPDR. Stage of retinopathy in this patient did not need special treatment, it was expected by good metabolic control progressivity of retinopathy could be delayed.

Screening for renal complication of this patient was done by measure microalbuminuria. Diabetic nephropathy in this patient was at third stage, cause of found microalbuminuria (+)/AER 30-300 $\mathrm{mg} / 24$ hour $(20-200 \mu \mathrm{g} / \mathrm{min})$. Patient was in normotensive and renal function still in normal range. In normotensive patients with microalbuminuria, ACEI reduce urinary albumin excretion. Good metabolic control and captopril administration were expected to postpone the progressivity of nephropathy and prolong time to end-stage renal failure. In adults with type 1 $\mathrm{DM}$, the presence of microalbuminuria in the second decade of the disease is highly predictive of progression to overt nephropathy or end-stage renal disease (ESRD) over the following 10-15 years. The progression of nephropathy in adolescents with microalbuminuria detected in the first decade of diabetes is somewhat less predictable than in adults. ${ }^{4,8}$

Poor metabolic control, younger age of onset and lower socioeconomic group are predictors of rehospitalization rates which may indicate poor adjustment to diabetes. ${ }^{4}$ Poor metabolic control of this patient might be cause of suboptimal education and less elementary knowledge of patient and family about diabetic and its management. Socioeconomic factor also contributed, even thought medical treatment was public charge by jamkesmas, but sometimes insulin preparation of jamkesmas was out of stock. And for self glucose monitoring, parent might be prepare own budget, so that blood glucose was not measured every 
day and if it was measured, it was not more than one a day, therefore adjustment of insulin dosages become less optimal. It needed more intensive education, better control of others family members to monitor compliance and suitability management with education was given. Donation was also needed to optimized therapy and maintained patient in a good metabolic control.

\section{Referencies}

1. Ammari F. Long-term complication of type 1 diabetes mellitus in western area of Saud Arabia. Diabetelogia Croatica 2004;33:59-63.

2. Kaufman FR. Type 1 diabetes mellitus. Pediatr Rev 2003;24:291-300.

3. Kaufman FR. Diabetes mellitus. Pediatr Rev 1997;18:383-93.

4. Australian Paediatric Endocrine Group. Clinical practice guidelines: Type 1 diabetes in children and adolescents. Canberra: Australian Government-National Health and Medical Research Council; 2005.
5. Alzadeh R, Wyatt $\mathrm{D}$. Diabetes mellitus. In: Kliegman RM, Behrman RE, Jenson HB, Stanton BF, editors. Nelson textbook of pediatrics. $18^{\text {th }}$ edition. Philadelphia: Saunders; 2007. p. 2404-32.

6. National Diabetes Education Program. Overview of diabetes in children and adolescents. New York: U.S. Department of Health and Human Services National Diabetes Education Program; 2006.

7. Dunger BD, Sperling MA, Acerini CL, et al. European society for paediatric endocrinology/Lawson Wilkins pediatric and adolescents endocrine society consensus statement on diabetic ketoacidosis in children and adolescent. Pediatrics 2004;113:e13340.

8. Chiarelli F, Santilli F. Diabetic nephropathy in children and adolescents. In: Diabetic retinopathy in children and adolescent with type 1 diabetes. In: Chiarelli F, DahlJorgenson K, Kiess WB, editors. Diabetes in childhood and adolescence. Basel: Karger; 2005. p.225-58. 